\title{
Collision Tumor Comprising Primary Malignant Lymphoma and Adenocarcinoma in the Ascending Colon
}

\author{
Jun Kataoka ${ }^{a}$ Toshikatsu Nitta ${ }^{a}$ Masato Ota ${ }^{a}$ Kensuke Fujii ${ }^{b}$ \\ Masatsugu Ishii ${ }^{a}$ Sadakatasu Senpuku ${ }^{a}$ Yasuhiko Ueda ${ }^{a}$ \\ Yusuke Tsuchimoto $^{c}$ Atsushi Takeshita $^{d}$ Junichi Miyatake \\ Takashi Ishibashi $^{\text {a }}$ \\ aDepartment of Surgery, Gastroenterological Center, Shunjukai Shiroyama Hospital, \\ Osaka, Japan; 'bepartment of General and Gastroenterological Surgery, Osaka Medical \\ College Hospital, Osaka, Japan; 'Department of Internal Medicine, Gastroenterological \\ Center, Shunjukai Shiroyama Hospital, Osaka, Japan; dDepartment of Pathology, Osaka \\ Medical College Hospital, Osaka, Japan; eDepartment of Hematology, Shunjukai \\ Shiroyama Hospital, Osaka, Japan
}

\section{Keywords}

Collision tumor Adenocarcinoma $\cdot$ Diffuse large B-cell lymphoma $\cdot$ lleocecal region

\begin{abstract}
We describe the case of a 78-year-old man with collision tumor from the primary malignant lymphoma and adenocarcinoma in the ascending colon. He suffered anemia from sigmoid colon cancer, and colonoscopy revealed early-stage colorectal cancer with a diameter of 20 $\mathrm{mm}$ in the cecum, the biopsy specimen showed moderately differentiated adenocarcinoma. Contrast-enhanced computed tomography (CT) revealed bowel wall thickening with contrast enhancement at the cecum; however, no lymph node and organ metastases were found. As
\end{abstract}

Karger $\begin{aligned} & \text { Jun Kataoka } \\ & \text { 2-8-1 Habikino } \\ & \text { Habikino City 583-0872 Osaka (Japan) } \\ & \text { kataoka@shiroyama-hsp.or.jp }\end{aligned}$




\section{Case Reports in Gastroenterology} \begin{tabular}{l|l}
\hline Case Rep Gastroenterol 2021;15:379-388 \\
\hline DOI: 10.1159/000513972 & $\begin{array}{l}\text { @ 2021 The Author(s). Published by S. Karger AG, Basel } \\
\text { www.karger.com/crg }\end{array}$ \\
\hline
\end{tabular}

Kataoka et al.: Collision Tumor Comprising Primary Malignant Lymphoma and Adenocarcinoma in the Ascending Colon

above, we performed laparoscopic ileocecal resection with D3 lymph node dissection. The postoperative course was uneventful, and he was discharged from the hospital on postoperative day 11 . Histopathological findings were moderately differentiated adenocarcinoma which invaded the muscularis propria and serosa from the submucosa, while the adjacent serosa showed a highly diffuse proliferation of atypical cells with an irregular nuclear-to-cytoplasmic ratio. Besides, immunohistochemical staining findings were diffuse large $B$-cell lymphoma, and diffuse large B-cell lymphoma was coexistent with moderately differentiated adenocarcinoma. We treated the patient with cyclophosphamide, doxorubicin, vincristine, and prednisolone in combination with rituximab (R-CHOP therapy) during 3 months postoperatively. When the 8 courses had been completed, postoperative positron emission tomography-CT (PET-CT) confirmed complete response, and the disease control has been doing well. Malignant lymphoma of the colorectal region is relative rare, and the occurrence of synchronous lymphoma and adenocarcinoma of the colon is also rare. Furthermore, collision tumor by these different entities is very unusual. We presented here such a case. The accurate clinical determination of the dominant tumor and a close follow-up is required for proper treatment in these cases.

(C) 2021 The Author(s)

Published by S. Karger AG, Basel

\section{Introduction}

Double cancers and multi-centric cancers have increasingly been reported in recent studies owing to an aging population and progress in diagnostic imaging. Two distinct malignant tumors that independently occur at the same site and combine to form one tumor are defined as collision tumors. Collison tumors were first described by Bernet in 1902 and modified by Meyer in 1919 [1]; they are frequently found in the stomach, wherein tumors such as lymphomas, gastrointestinal stromal tumors, and carcinoids may occur in collision with gastric adenocarcinomas. However, collision tumors of the colon, especially those combining colorectal adenocarcinomas and lymphomas, are extremely rare, with only a few cases reported in the literature. Moreover, primary extra-nodal malignant lymphomas frequently involve the gastrointestinal tract, with the stomach being the most common location (50-60\%) followed by the small intestine (30\%), while those involving the colon and rectum are rare, accounting for only $0.2-1.2 \%$ of all colorectal malignancies [2]. The most frequently involved colorectal site is the ileocecal region (approximately 50\%), followed by the cecum, sigmoid colon, and rectum.

Herein, we report a case of collision tumor comprising a primary malignant lymphoma and an adenocarcinoma located in the ascending colon. A review of the pertinent literature was also performed.

\section{Karger's}




\section{Case Reports in Gastroenterology}

\begin{tabular}{l|l}
\hline Case Rep Gastroenterol 2021;15:379-388 \\
\hline DOI: 10.1159/000513972 & $\begin{array}{l}\text { (c) 2021 The Author(s). Published by S. Karger AG, Basel } \\
\text { www.karger.com/crg }\end{array}$ \\
\hline
\end{tabular}

Kataoka et al.: Collision Tumor Comprising Primary Malignant Lymphoma and Adenocarcinoma in the Ascending Colon

\section{Case Presentation}

A 78-year-old Japanese man visited the Department of Internal Medicine of the Gastroenterological Center at the Shunjukai Shiroyama Hospital for an anemia examination. He had previously undergone surgeries for cholelithiasis, acute appendicitis, and abdominal aortic aneurysm. Results of laboratory tests conducted on admission revealed that his hemoglobin, hematocrit, and lactate dehydrogenase levels were $11.0 \mathrm{~g} / \mathrm{dL}, 35.7 \%$, and $214 \mathrm{U} / \mathrm{L}$, respectively. The remaining hematologic parameters, including serum carcinoembryonic antigen level $[1.6 \mathrm{ng} / \mathrm{dL}]$ and carbohydrate antigen $19-9$ level $[2.0 \mathrm{U} / \mathrm{mL}]$ were within normal ranges (Table 1). Total colonoscopy detected a 20 -mm-sized ulcerative mass in the ascending colon (Fig. 1a, b). A biopsy specimen from the mass revealed a moderately differentiated adenocarcinoma of the colon. Contrast-enhanced chest and abdominal computed tomography (CT) showed wall thickening in the ileocecal tract. There was no indication of metastasis to the lymph nodes, liver, and lung. We, therefore, identified the tumor as a clinical stage I (T2N0M0) colon carcinoma according to the tumor node metastasis classification. The patient was subsequently scheduled for a laparoscopic ileocecal resection with D3 lymph node dissection. Under general anesthesia, the surgery was performed with the patient in the supine position. The total operating time was $275 \mathrm{~min}$, and the intraoperative blood loss was $5 \mathrm{~mL}$. The patient's postoperative course was uneventful, and he was discharged after 11 days.

The specimen was of a moderately differentiated adenocarcinoma of the colon that had invaded the muscularis propria and serosa from the submucosa (Fig. 2). Highly diffused proliferation of atypical cells with irregular nuclear-to-cytoplasmic ratio was observed in the adjacent serosa; however, there was no evidence that it had spread to the lymph nodes (Fig. 3ac). Immunohistochemical analyses showed that the cells were positive for cluster of differentiation (CD)20, CD79 $\alpha$, CD3, and B-cell lymphoma (Bcl)-6 and negative for CD10, Bcl-2, and Epstein Barr virus nuclear antigen2 (Fig. 3d-o). The MIB-1 labeling index was approximately $90-95 \%$. The morphological and immunohistochemical findings confirmed the diagnosis of collision tumor comprising a diffuse large B-cell lymphoma and moderately differentiated adenocarcinoma, wherein the adenocarcinoma in muscularis propria was coexistent with the diffuse large B-cell lymphoma that invaded the muscularis propria and serosa from the submucosa.

Postoperative positron emission tomography-CT (PET-CT) revealed the presence of a hypermetabolic lesion (standardized uptake value [SUV]: 24.56) in the right lower abdomen and ascending colon; there was no evidence of metastasis to the bone marrow. Based on these findings, the patient received eight courses of combined chemotherapy, comprising cyclophosphamide, doxorubicin, vincristine, and prednisolone regimen with rituximab (R-CHOP therapy), for 3 months postoperatively without adjuvant chemotherapy for the adenocarcinoma of the colon. PET-CT performed after the chemotherapy course revealed that the extent of the hypermetabolic lesion (SUV:5.35) had reduced. A complete response was obtained, and the patient is alive and almost free of disease at the 4-year follow-up. 


\section{Case Reports in Gastroenterology}

\begin{tabular}{l|l}
\hline Case Rep Gastroenterol 2021;15:379-388 \\
\hline DOI: 10.1159/000513972 & $\begin{array}{l}\text { @ } 2021 \text { The Author(s). Published by S. Karger AG, Basel } \\
\text { www.karger.com/crg }\end{array}$ \\
\hline
\end{tabular}

Kataoka et al.: Collision Tumor Comprising Primary Malignant Lymphoma and

Adenocarcinoma in the Ascending Colon

\section{Discussion}

A collision tumor is a true coexistence of two malignant neoplasms that are histologically different, but are found in the same organ without an intermediate cell area. Such tumors consist of components with differing histogenesis and tumorigenesis, representing a mosaic of two concurrent but independent tumors that "bumped" into one another. There exist few hypotheses that suggest the possible etiology of such tumors.

One hypothesis is that two primary tumors arise in continuity through an accidental "meeting." To date, however, there are no known common etiologic factors for the occurrence of both adenocarcinoma and malignant lymphoma in the colon. Another hypothesis is that the presence of the first tumor alters the microenvironment, triggering the development of the second adjacent tumor [3].

Although the formation of collision tumors is not well understood, theories explain their occurrence as follows: (1) simultaneous proliferation of two different cell lines, (2) common origin from a pluripotent cancerous stem cell that differentiates into two components, and (3) chance apposition of two unrelated tumors [4]. Meyer named such tumors based on the above stated theories as (1) collision tumor, (2) combination tumor, and (3) composition tumor. Thus, collision tumors are morphologically neighboring synchronous neoplasms that developed independently in latero-lateral territories within the same organ. However, it is difficult to predict the biological behavior of a collision tumor. Moreover, diagnosing a collision or synchronous tumor preoperatively from a biopsy specimen and through image inspection is challenging. Molecular genetic analysis is of special importance in diagnosing collision tumors comprising poorly differentiated neoplasms, such as peripheral T-cell lymphomas and anaplastic carcinomas, when immunohistochemical findings are inconclusive. Therefore, collision tumors comprising large cell non-Hodgkin's lymphomas and carcinomas might have been detected more often if molecular genetic analysis was performed more extensively [5].

Collision tumors comprising colorectal adenocarcinoma and lymphoma are extremely rare, and only a few cases have been reported in the literature. A search for case reports published from April 2004 to December 2019 in the Japan Medical Abstracts Society and PubMed databases using the keywords "collision tumor," "adenocarcinoma in the colon," and "malignant lymphoma" yielded reports of 14 cases, including the present one (Table 2) [3-15].

We describe the common clinical characteristics observed on reviewing these reported cases (Table 2). The patients were aged between 62 and 81 years, and the male to female ratio was 10:2. The location of the collision tumor was varied: the most common sites were the ileocecal region and cecum (5 cases), followed by the sigmoid and recto-sigmoid colon (4 cases), ascending colon ( 4 cases, including the present case), and the rectum ( 1 cases). The most common histologic subtype of the lymphoma was B-cell lymphoma (10 cases), followed by follicular lymphoma ( 3 cases), and others ( 1 cases). Among the 9 cases with data available on histopathologic staging of adenocarcinoma, 3 tumors were stage I, 2 were stage II, 3 were stage III, and 1 was stage IV. Most patients had symptoms associated with colorectal adenocarcinomas.

The treatment of collision tumors (colorectal cancer and malignant lymphoma), the clinical strategy involves surgical resection, chemotherapy, radiotherapy, or a combination of 


\section{Case Reports in Gastroenterology}

Case Rep Gastroenterol 2021;15:379-388

DOI: $10.1159 / 000513972$

(C) 2021 The Author(s). Published by S. Karger AG, Basel www.karger.com/crg

Kataoka et al.: Collision Tumor Comprising Primary Malignant Lymphoma and Adenocarcinoma in the Ascending Colon

these. The order of treatment can be a source of debate because it has not been established which tumor should be treated first. Evidence-based management according to long-term outcomes is not well defined because of the rarity of these tumors [15]. The treatment protocol is usually decided after the surgical resection because of the difficulty in diagnosing such tumors preoperatively. Our review of the literature showed that tumors in 2 cases were diagnosed macroscopically and those in 12 cases preoperatively; there was only 1 case in which diagnosis was made after chemotherapy (R-CHOP) [4]. In 13 cases, surgical resection was selected as the initial course of treatment, while in 1 case, the patient underwent surgical resection after chemotherapy [15].

In the present case, we performed surgical resection because the preoperative diagnosis indicated a moderately differentiated adenocarcinoma of the colon. However, morphological and immunohistochemical findings showed simultaneous proliferation of two different cell lines in the biopsy specimen. The adenocarcinoma of the colon invaded the muscularis propria and serosa from the submucosa, while the adjacent serosa showed a highly diffuse proliferation of atypical cells with an irregular nuclear-to-cytoplasmic ratio. Subsequently, these tumors were diagnosed as a collision tumor, and the patient received R-CHOP chemotherapy after surgery because of the stage I (T2N0M0) adenocarcinoma in the colon.

In conclusion, in our case, the collision tumor comprising a primary malignant lymphoma and an adenocarcinoma in the ascending colon was found incidentally through postoperative molecular genetics and immunohistochemical analyses, thus highlighting the importance of these techniques in detecting collision tumors that can be challenging to diagnose in the clinical environment. The treatment strategy of such tumors depends on preoperative findings, postoperative staging system, evaluation, and clinical difference of the involved tumors.

\section{Statement of Ethics}

Approval for the study was granted by the Institutional Review Board of the Department of Gastroenterological Center Surgery, Shunjukai Shiroyama Hospital, and written informed consent for publication was obtained from the patient.

\section{Conflict of Interest Statement}

The authors have no conflicts of interest to disclose.

\section{Funding Sources}

No funding was received.

\section{Karger'=}




\section{Case Reports in Gastroenterology}

\begin{tabular}{l|l}
\hline Case Rep Gastroenterol 2021;15:379-388 \\
\hline DOI: 10.1159/000513972 & $\begin{array}{l}\text { ( ) 2021 The Author(s). Published by S. Karger AG, Basel } \\
\text { www.karger.com/crg }\end{array}$ \\
\hline
\end{tabular}

Kataoka et al.: Collision Tumor Comprising Primary Malignant Lymphoma and Adenocarcinoma in the Ascending Colon

\section{Author Contributions}

Each author has participated sufficiently in the work to take public responsibility for appropriate portions of the content. K. Jun, N. Toshikatsu, T. Yusuke, M. Junichi and I. Takashi analyzed histopathological features and drafted the manuscript. K. Jun, N. Toshikatsu, O. Masato, S. Sadakatsu, U. Yasuhiko, I. Masatsugu, and F. Kensuke, a team of attending doctors of the present case, earnestly discussed clinical problems. T. Atsushi provided valuable advice and suggestions as a histopathologic consultant and contributed to part of the molecular study. All authors read and approved the final manuscript.

\section{References}

1 Meyer R. Beitrag zur verstandigung uber die namengebung in der geschwurstiehre. Zentralbl Allg Pathol. 1919;30:291-6.

2 She WH, Day W, Lau PY, Mak KL, Yip AW. Primary colorectal lymphoma: case series and literature review. Asian J Surg. 2011 Jul;34(3):111-4.

3 Shigeno T, Fujimori K, Tsuruta F, Nozawa Y, Nagaya T, Maejima T. Ileocecal collision tumor composed of adenocarcinoma and primary malignant lymphoma. Clin J Gastroenterol. 2011 Apr;4(2):79-84.

4 Sathaya G, Ramkumar G, Ganesh P, Kumar SJ. Collision tumour of sigmoid colon - a rare presentation. Trop Gastroenterol. 2014 35(2):120-2.

5 Linn HH, Jiang JK, Lin JK. Collision tumor of low-grade B-cell lymphoma and adenocarcinoma with tuberculosis in the colon: a case report and literature review. World J Surg Oncol. 2014 May;12:147.

6 Minato E, Fujino I, Sugihira N, Matsumoto K, Shima K. A case of collision tumor of primary malignant lymphoma and poorly- differentiated adenocarcinoma in the ascending colon. Jpn J Gastroenterol Surg. 2004;37(2):213-6. Japanese.

7 Amano M, Nakagawa S, Higaki N. A case of collision tumor of primary malignant lymphoma and welldifferentiated adenocarcinoma in the ascending colon. Jpn J Society of Coloproctology. 2005;58:641. Japanese.

8 Sasaki S, Hatanaka K, Sahara N, Uekusa T, Hirayama K, Shirahata A, et al. Collision tumor of primary malignant lymphoma and adenocarcinoma in the colon: report of a case. Surg Today. 2010 Oct;40(10):97581.

9 Tokoro T, Okuno K, Hida J, Ishimaru E, Ueda K, Yoshifuji T. Collision tumor of malignant lymphoma and adenocarcinoma in the rectum - report a case. Journal of Clinical Surgery. 2010;71(5):1236-40. Japanese.

10 Eshra A, Al-Hendal A, Al Enezi M, Al-Mishaan M, Abo Dief W. One patient, two lymphomas, three primaries. Gulf J Oncolog. 2010 Jul;1(8):39-43.

11 Chang H, Chuang WY, Shih LY, Tang TC. Collision in the colon: concurrent adenocarcinoma and diffuse large B-cell lymphoma in the same tumour. Acta Clin Belg. 2011 Jul-Aug;66(4):302-4.

12 Lee DY, Hong SW, Chang YG, Lee WY, Lee B, Kang YK. Synchronous T-cell lymphoma in patient with colon cancer: a case report. J Korean Surg Soc. 2012 Jul;83(1):60-4.

13 Kus T, Aktas G, Kalender ME, Sari I, Ulker E, Camci C. Collision tumor consisting of primary follicular lymphoma and adenocarcinoma in the cecum: A case report and literature review. Oncol Lett. 2016 Apr;11(4):2801-5.

14 Soto AR, Vazquez EG, Grigg-Gutierrez NM, Magno-Pagatzaurtundua P, Cáceres W, Toro DH. Conundrum of a Large Bowel Neoplasm: Collision Tumor. ACG Case Rep J. 2018 Feb;5(1):e13.

15 Kim SH. Collision Tumor of Adenocarcinoma and Diffuse Large B-Cell Lymphoma in the Rectum: A Case Report and Literature Review. iMRI. 2019;23:374-80. 


\section{Case Reports in Gastroenterology}
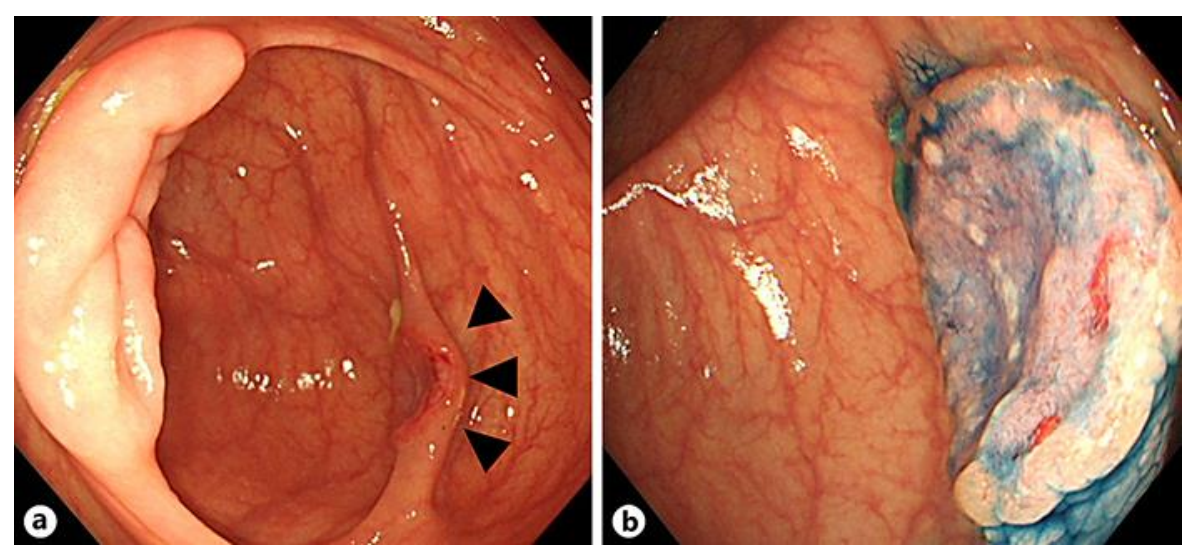

Fig. 1. Preoperative total colonoscopy. a, b Total colonoscopy detected a 20-mm-sized ulcerative mass in the ascending colon (black arrow), and a biopsy specimen from the mass revealed a moderately differentiated adenocarcinoma of the colon.

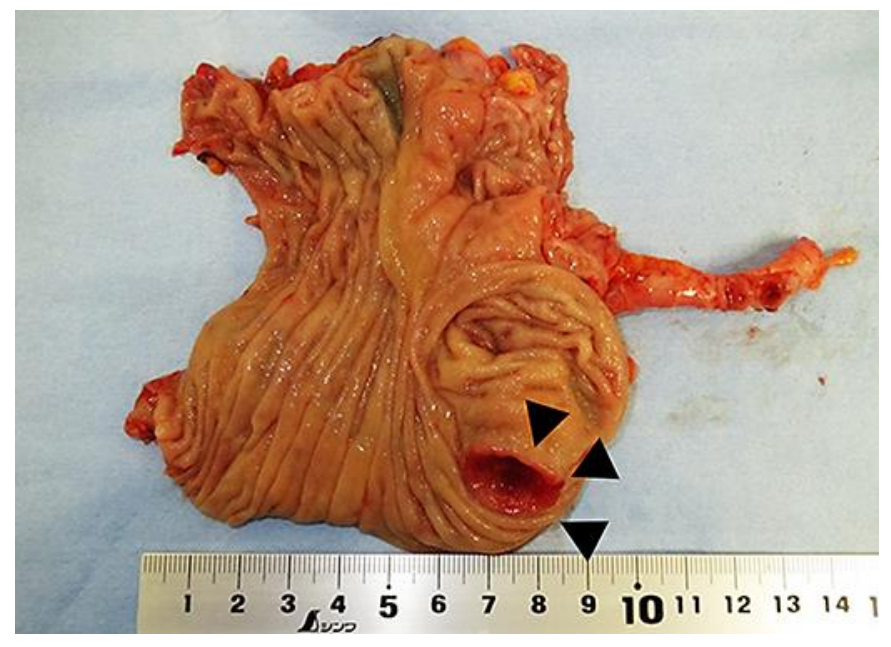

Fig. 2. Macroscopic findings. The specimen showed a long ulcerative mass with a diameter of $18 \mathrm{~mm}$, a moderately differentiated adenocarcinoma of the colon which invaded the muscularis propria and serosa from the submucosa. 


\section{Case Reports in Gastroenterology}
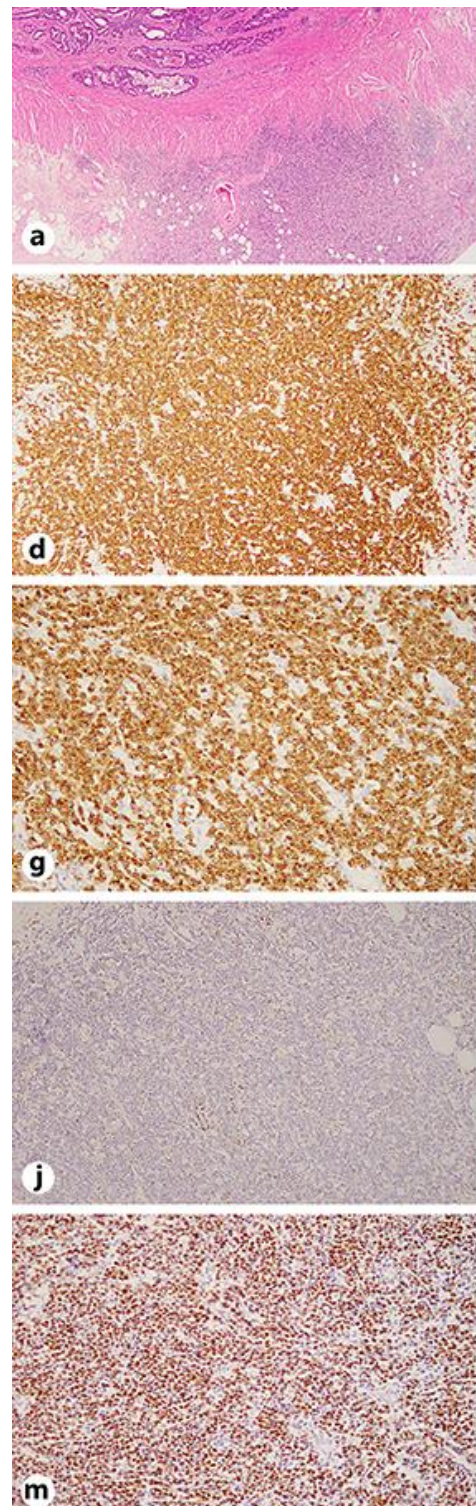

m

\begin{tabular}{l|l}
\hline Case Rep Gastroenterol 2021;15:379-388 \\
\hline DOI: 10.1159/000513972 & $\begin{array}{l}\text { @ 2021 The Author(s). Published by S. Karger AG, Basel } \\
\text { www.karger.com/crg }\end{array}$ \\
\hline
\end{tabular}

Kataoka et al.: Collision Tumor Comprising Primary Malignant Lymphoma and Adenocarcinoma in the Ascending Colon
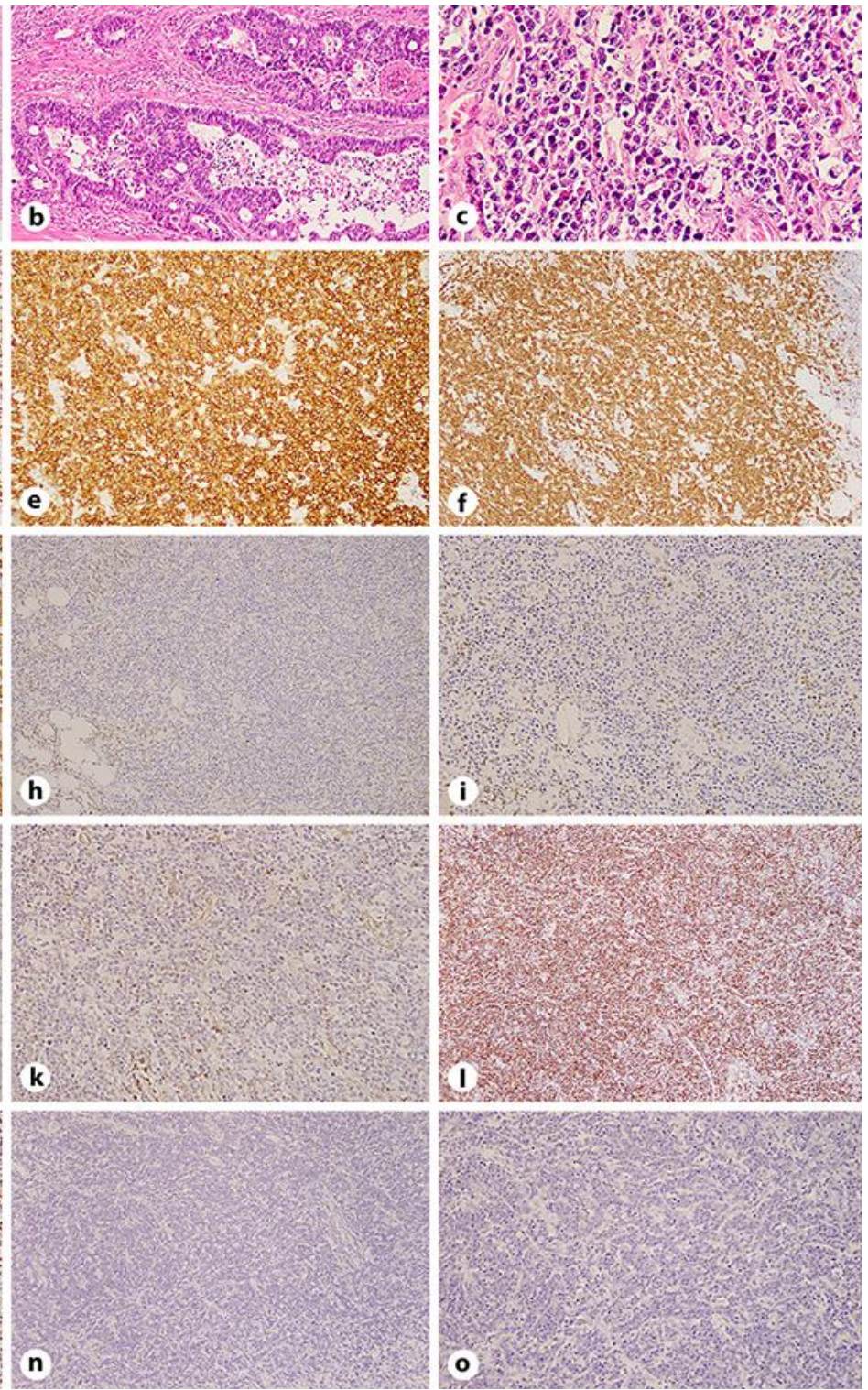

Karger' 


\section{Case Reports in Gastroenterology}

\begin{tabular}{l|l}
\hline Case Rep Gastroenterol 2021;15:379-388 \\
\hline DOI: 10.1159/000513972 & $\begin{array}{l}\text { (c) 2021 The Author(s). Published by S. Karger AG, Basel } \\
\text { www.karger.com/crg }\end{array}$ \\
\hline
\end{tabular}

Kataoka et al.: Collision Tumor Comprising Primary Malignant Lymphoma and Adenocarcinoma in the Ascending Colon

Fig. 3. Microscopic, morphological, and immunohistochemical findings. a A photograph of the specimen (hematoxylin and eosin [H\&E] staining, original magnification 40x) shows evidence of a colliding lymphoma (lower) and moderately differentiated adenocarcinoma (upper). b H\&E-stain of moderately differentiated adenocarcinoma that invaded the muscularis propria and serosa from the submucosa (original magnification $100 \times$ ). c H\&E-stain of highly diffused proliferation of atypical cells with irregular nuclearto-cytoplasmic ratio was observed in the adjacent serosa (original magnification 100x); and cytoplasmic immunohistochemical positivity for B-cell marker cluster of differentiation 20 through; $\mathbf{d}$ immunochemical staining 20x, and e immunochemical staining 40x, for cluster of differentiation (CD) 20; fimmunochemical staining 20×, and g immunochemical staining 40×, for CD79 $\alpha$; h immunochemical staining 20×, and i immunochemical staining 40× for CD 3; j immunochemical staining 20x, and k immunochemical staining 40×, for B-cell lymphoma (Bcl)-2; I immunochemical staining 20x, and $\mathbf{m}$ immunochemical staining $40 \times$, for Bcl6; n immunochemical staining 20x, and o immunochemical staining $40 \times$, for Epstein Barr virus nuclear antigen2.

Table 1. Laboratory findings

\begin{tabular}{|c|c|c|c|c|c|}
\hline \multirow{2}{*}{$\begin{array}{l}\text { Peripheral } \\
\text { WBC }\end{array}$} & \multirow{2}{*}{$\begin{array}{l}\text { blood } \\
5,100 / \mu \mathrm{L}\end{array}$} & \multicolumn{2}{|c|}{ Blood chemistry } & \multicolumn{2}{|c|}{ Serological tests } \\
\hline & & $\mathrm{TP}$ & $7.7 \mathrm{~g} / \mathrm{dL}$ & CRP & $0.49 \mathrm{mg} / \mathrm{dL}$ \\
\hline $\mathrm{RBC}$ & $490 \times 104 / \mu \mathrm{L}$ & Alb & $4.4 \mathrm{~g} / \mathrm{dL}$ & HBsAg & $(-)$ \\
\hline $\mathrm{Hb}$ & $11.0 \mathrm{~g} / \mathrm{dL}$ & T-Bil & $0.6 \mathrm{~m} \mathrm{~g} / \mathrm{dL}$ & $\mathrm{HBsAb}$ & $(-)$ \\
\hline Hct & $35.7 \%$ & AST & $55 \mathrm{U} / \mathrm{L}$ & HCVAb & $(-)$ \\
\hline \multirow[t]{10}{*}{ Plt } & $26.7 \times 104 / \mu \mathrm{L}$ & ALT & $46 \mathrm{U} / \mathrm{L}$ & Coagulation & \\
\hline & & ALP & $243 \mathrm{U} / \mathrm{L}$ & PT & $14.0 \mathrm{~s}$ \\
\hline & & $\gamma$-GTP & $212 \mathrm{U} / \mathrm{L}$ & PT-INR & 1.26 \\
\hline & & $\mathrm{LDH}$ & $214 \mathrm{U} / \mathrm{L}$ & APTT & $48.5 \mathrm{~s}$ \\
\hline & & BUN & $13 \mathrm{mg} / \mathrm{dL}$ & Others & \\
\hline & & Cre & $0.91 \mathrm{mg} / \mathrm{dL}$ & CEA & $1.6 \mathrm{ng} / \mathrm{mL}$ \\
\hline & & $\mathrm{Na}$ & $141 \mathrm{mEq} / \mathrm{L}$ & CA19-9 & $2 \mathrm{U} / \mathrm{mL}$ \\
\hline & & $\mathrm{K}$ & $4.2 \mathrm{mEq} / \mathrm{L}$ & & \\
\hline & & $\mathrm{Cl}$ & $105 \mathrm{mEq} / \mathrm{L}$ & & \\
\hline & & $\mathrm{CPK}$ & $18 \mathrm{U} / \mathrm{L}$ & & \\
\hline
\end{tabular}

Routine blood test showed that the hemoglobin level was $11.0 \mathrm{~g} / \mathrm{dl}$, hematocrit level was $35.7 \%$, lactate dehydrogenase (LDH) level was $214 \mathrm{U} / \mathrm{L}$. The remainder of the hematologic parameters was within the normal range, including serum carcinoembryonal antigen (CEA) level (1.6 ng/dL) and carbohydrate antigen 19-9 level (2.0 U/mL). 


\section{Case Reports in Gastroenterology}

\begin{tabular}{l|l}
\hline Case Rep Gastroenterol 2021;15:379-388 \\
\hline DOI: 10.1159/000513972 & $\begin{array}{l}\text { @ 2021 The Author(s). Published by S. Karger AG, Basel } \\
\text { www.karger.com/crg }\end{array}$ \\
\hline
\end{tabular}

Kataoka et al.: Collision Tumor Comprising Primary Malignant Lymphoma and

Adenocarcinoma in the Ascending Colon

Table 2. A search for case reports published from April 2004 to December 2019 in the Japan Medical Abstracts Society and PubMed databases*

\begin{tabular}{|c|c|c|c|c|c|c|c|c|c|}
\hline Author & Year & $\begin{array}{l}\text { Age/ } \\
\text { sex }\end{array}$ & Lo-cation & Morphology & Morphology & Diagnosis & Chemotherapy & Stage & Outcome \\
\hline Minato [6] & 2004 & $80 / \mathrm{M}$ & $\mathrm{A}$ & DLBCL & Poorly & Micro & none & pT2N0M0 & dead \\
\hline Amano [7] & 2005 & $69 / \mathrm{M}$ & A & Well & DLBCL & Micro & not applicable & not applicable & not applicable \\
\hline Sasaki [8] & 2010 & $62 / \mathrm{M}$ & $\mathrm{C}$ & Adeno & FL & Micro & $\mathrm{R}-\mathrm{CHOP} \rightarrow \mathrm{mFOLFOX6}$ & pT3N0M0 & alive \\
\hline Tokoro [9] & 2010 & $70 / \mathrm{M}$ & $\mathrm{Ra}$ & Moderately & DLBCL & Micro & none & pT3N0M0 & dead \\
\hline Eshra [10] & 2010 & $\begin{array}{l}\text { not applica- } \\
\text { ble }\end{array}$ & $\mathrm{A}$ & Moderately & FL & Micro & not applicable & not applicable & not applicable \\
\hline Shigeno [3] & 2011 & $76 / \mathrm{F}$ & $\mathrm{C}$ & Adeno & DLBCL & Micro & not applicable & pT3N1M0 & not applicable \\
\hline Chang [11] & 2011 & $\begin{array}{l}\text { not applica- } \\
\text { ble }\end{array}$ & $\mathrm{C}$ & Adeno & DLBCL & Macro & not applicable & not applicable & not applicable \\
\hline Lee [12] & 2012 & $79 / \mathrm{F}$ & $\mathrm{C}$ & Poorly & AITL & Micro & not applicable & not applicable & not applicable \\
\hline $\operatorname{Lin}[5]$ & 2014 & $81 / \mathrm{M}$ & $\mathrm{S}$ & Moderately & DLBCL & Micro & mFOLFOX6 & pT3N1aM1 & alive \\
\hline Sathya [4] & 2014 & $77 / \mathrm{M}$ & $S$ & Poorly & high grade $\mathrm{BCL}$ & Macro & chemotherapy & not applicable & alive \\
\hline Kus [13] & 2016 & $73 / \mathrm{M}$ & $\mathrm{C}$ & Moderately & FL & Micro & FOLFOX4 $\rightarrow$ R-CHOP & pT3N1M0 & alive \\
\hline Soto [14] & 2018 & $79 / \mathrm{M}$ & Rs & Moderately & DLBCL & Micro & $\mathrm{R}-\mathrm{CHOP} \rightarrow$ FOLFOX 4 & pT3N2aM0 & alive \\
\hline Kim [15] & 2019 & $62 / \mathrm{M}$ & Rs & Moderately & DLBCL & Macro & $\mathrm{R}-\mathrm{CHOP} \rightarrow$ FOLFOX 4 & pT2NOM0 & alive \\
\hline Our case & 2020 & $78 / \mathrm{M}$ & $\mathrm{A}$ & Moderately & DLBCL & Micro & R-CHOPx8 & pT2N0M0 & alive \\
\hline
\end{tabular}

*oThe following keywords were used: "collision tumor," "adenocarcinoma in the colon," and "malignant lymphoma” yielded reports of 14 cases including the present one. A, ascending colon; C, cecum; S, sigmoid colon; T, transverse colon; R, rectum; Adeno, adenocarcinomas; Well, well differentiated adenocarcinomas; Moderately, moderately differentiated adenocarcinomas; Poorly, poorly differentiated adenocarcinomas; DLBCL, diffuse large B-cell lymphoma; FL, follicular lymphoma; FOLFOX, oxaliplatin chemotherapy with leucovorin and 5-uorouracil; R-CHOP, cyclophosphamide, doxorubicin, vincristine, prednisolone regimen with rituximab. 